\title{
Glucocorticoid Receptors and Actions in Subpopulations of Cultured Rat Bone Cells
}

\author{
MECHANISM OF DEXAMETHASONE POTENTIATION OF \\ PARATHYROID HORMONE-STIMULATED CYCLIC AMP PRODUCTION
}

\author{
Theresa L. Chen and David Feldman, Department of Medicine, Stanford University \\ School of Medicine, Stanford, California 94305
}

\begin{abstract}
A B S T RACT We have previously shown that bone cells possess glucocorticoid receptors and that, in addition to being inhibitory to cell growth, glucocorticoid treatment potentiates the ability of parathyroid hormone (PTH) to stimulate cyclic AMP (cAMP) formation. This study extends those observations to specific subpopulations of bone cells and explores the mechanism of the cAMP augmentation. Subpopulations of cultured bone cells derived from 20-d-old fetal rat calvaria were enriched for "osteoblast-like" $(\mathrm{OB})$ and "osteoclast-like" $(\mathrm{OC})$ cells by sequential collagenase digestion. OC cells released during the first $30 \mathrm{~min}$ of collagenase digestion were characterized by low alkaline phosphatase activity, a cAMP response to salmon calcitonin (CT), but only a small cAMP response to bovine $\mathrm{PTH}$. In contrast, $\mathrm{OB}$ cells released between 30 and $120 \mathrm{~min}$ of collagenase digestion, possessed high alkaline phosphatase activity, responded with a large cAMP rise to PTH, but exhibited no response to CT. Glucocorticoid receptors, with similar properties, were demonstrated in both populations $\left(K_{\mathrm{d}} \cong 5 \mathrm{nM}, \mathrm{N}_{\text {maximum }} \cong 400 \mathrm{fmol} / \mathrm{mg}\right.$ cytosol protein). Dexamethasone equivalently inhibited cell growth and alkaline phosphatase activity in both populations. Dexamethasone potentiation of cAMP generation occurred after PTH but not CT stimulation. A greater enhancement of cAMP generation observed in OB cells appears to result from two glucocorticoid actions: (a) stimulation of adenylate cyclase and $(b)$ inhibition
\end{abstract}

This study was presented in part at The 60th Annual Meeting of the Endocrine Society, Miami Beach, Fla., June 1978.

Dr. Chen worked on this study during the tenure of her National Institutes of Health fellowship AM05503. Dr. Feldman is a Howard Hughes Medical Institute investigator.

Received for publication 7 August 1978 and in revised form 7 December 1978. of phosphodiesterase. Only the latter mechanism was found in OC cells. Dexamethasone-treated cells showed an increase in both sensitivity and maximal response of CAMP to PTH. The possible relationship of these actions to the mechanism of glucocorticoidinduced osteopenia is discussed.

\section{INTRODUCTION}

Glucocorticoid excess results in osteopenia. This detrimental action of glucocorticoids on bone is probably mediated both directly at the level of the bone as well as indirectly by inhibition of $\mathrm{Ca}^{++}$absorption from the gastrointestinal tract. We have previously demonstrated the presence of glucocorticoid receptors in bone cells $(1,2)$, and we, and others, have shown that glucocorticoids exert a direct inhibitory action on bone cell function (2-4). However, all of these studies were performed on mixed populations of bone cells. Recently, Wong and Cohn (5) and Peck et al. (6) have developed techniques to separate rodent bone cells into distinct populations possessing properties characteristic of osteoblasts and osteoclasts. We felt it would be of great interest to determine which of these populations possessed glucocorticoid receptors and, if both cell types were glucocorticoid targets, to ascertain whether glucocorticoids elicited different actions in each cell type. Moreover, we have recently demonstrated that glucocorticoid treatment potentiates the ability of parathyroid hormone $(\mathrm{PTH})^{1}$ to stimulate cyclic AMP (cAMP) generation in mixed bone cells (7). Employing separated bone cells would allow us to differentiate whether PTH was enhancing

\footnotetext{
${ }^{1}$ Abbreviations used in this paper: BSA, bovine serum albumin; cAMP, cyclic AMP; CT, calcitonin; $\mathrm{G}_{\mathrm{pp}}(\mathrm{NH})_{\mathrm{p}}$, guanylyl imidodiphosphate; $\mathrm{OB}$, osteoblast-like; $\mathrm{OC}$, osteoclast-like; PTH, parathyroid hormone.
} 
cAMP in osteoblast, osteoclast, or both populations, as well as to compare the glucorticoid effect on PTHstimulated CAMP with that of calcitonin (CT). By identifying the separate actions of glucocorticoids on the two major bone cell types, it was hoped that these studies would shed further light on the mechanisms by which glucocorticoid excess leads to osteopenia.

\section{METHODS}

Culture of different populations of bone cells. Bone cells from 20-d-old fetal rat calvaria were dispersed by collagenase digestion and cultured as previously described (2) except for the use of autoclavable minimum essential medium with Earle's salts (F-17, Grand Island Biological Co., Grand Isand, N. Y.) instead of filtered minimum essential medium (F-11). The growth pattern, biochemical response, and morphology of the cells cultured in these two media were essentially the same. To separate bone cells into different subpopulations, two techniques were used; $(a)$ the method of Peck et al. (6) employed mechanical scraping of periosteal and endosteal tissues to obtain osteoclasts, leaving residual osteoblasts to be digested with collagenase, and $(b)$ the method of Wong and Cohn (5) employed timed, sequential, enzymatic digestion with collagenase. In some early experiments, both methods were used. In both cases, the collagenase incubation was performed at $37^{\circ} \mathrm{C}$ with $2 \mathrm{mg} / \mathrm{ml}$ of enzyme (CLS II, Worthington Biochemical Corp., Freehold, N. J.) in a gyratory water bath shaker at $175 \mathrm{rpm} / \mathrm{min}$. In later experiments, only enzymatic digestion was employed. The populations designated "OC" (indicating osteoclast-like) were released during the first $30 \mathrm{~min}$ of collagenase digestion, and the populations designated " $\mathrm{OB}$ " (indicating osteoblast-like) were released during the following $90 \mathrm{~min}$ of digestion; that is, between 30 and $120 \mathrm{~min}$. Cells were cultured separately for 6-7 d, at which time both populations reached confluency. Except for the cell growth studies, dexamethasone treatments were generally made $2 \mathrm{~d}$ before termination of the experiment. Dexamethasone added to the culture near confluency did not change the cell number.

Hormonal stimulation of cAMP generation. On the day of the experiment, cells in 6-oz glass bottles, pretreated with vehicle $(0.05 \%)$ or dexamethasone, were incubated in serumfree medium containing $1 \mathrm{mg} / \mathrm{ml}$ bovine serum albumin (BSA), $25 \mathrm{mM}$ Hepes, and $0.01 \mathrm{mM}$ of isobutylmethyl xanthine (Aldrich Chemical Co., Inc., Milwaukee, Wis.) for 10 min. Synthetic bovine PTH (PTH 1-34 peptide, 3,820 IU/mg, Beckman Instruments Inc., Spinco Div., Palo Alto, Calif.) or synthetic salmon CT (4,700 Medical Research Council U/mg, a gift from Dr. James Bastian, Armour Pharmaceutical Co., Chicago, Ill.) was added for $2 \mathrm{~min}$. The period of hormonal stimulation was terminated by removal of the medium, washing with Dulbecco's $\mathrm{Ca}^{++}{ }^{-} \mathrm{Mg}^{++}$-free phosphate-buffered saline, and immediate addition of absolute ethanol. In doseresponse studies (as illustrated by Fig. 4), to conserve hormones, cells were scraped from large culture bottles and suspended in $1 \mathrm{ml}$ of BSA medium in 1.5-ml plastic centrifuge tubes to which PTH or CT was added. The reaction was terminated by a 30-s centrifugation in a microfuge (Model B, Beckman Instruments, Inc., Spinco Div.), removal of the medium, and the addition of ethanol. The amount of cAMP extracted by ethanol was assayed by the protein-binding method of Gilman (8) with modifications as previously described (7).

Glucocorticoid receptor binding assay. After $7 \mathrm{~d}$ in culture, monolayers in liter-size glass bottles were digested with collagenase solution $(1 \mathrm{mg} / \mathrm{ml}$ collagenase, $1 \mathrm{mg} / \mathrm{ml}$ glucose in phosphate-buffered saline) to remove extracellular matrix. The cells were then lysed with a Dounce homogenizer (Kontes Co., Vineland, N. J.) in hypotonic buffer A (10 mM Tris, $0.1 \mathrm{mM}$ EDTA, $1 \mathrm{mM}$ thioglycerol). Cytosol was prepared and binding was performed at $0^{\circ} \mathrm{C}$ for $4 \mathrm{~h}$. Free $\left[{ }^{3} \mathrm{H}\right]$ dexamethasone was removed by charcoal adsorption. One-tenth the incubation volume of charcoaldextran mixture $(0.5 \mathrm{mg}$ of Norit A [American Norit Co., Jacksonville, Fla.] plus $0.05 \mathrm{mg}$ Dextran T70 [Pharmacia Fine Chemicals Inc., Piscataway, N. J.] per milliliter) was added to the $\left[{ }^{3} \mathrm{H}\right]$ dexamethasone-labeled cytosol and, after $20 \mathrm{~min}$ incubation at $0^{\circ} \mathrm{C}$, the charcoal-dextran pellet was removed by centrifugation $(2,000 \mathrm{~g}$ for $10 \mathrm{~min})$, and an aliquot of supernate was radioassayed for bound $\left[{ }^{3} \mathrm{H}\right]$ dexamethasone. Another aliquot from the supernate was taken for protein determination by the method of Bradford (9).

Cell growth and alkaline phosphate assay. Cells were grown in 1.6-cm diameter plastic multiwelled dishes (Linbro Chemical Company, Hamden, Conn.). In cell growth experiments, cultures were changed to medium containing varying concentrations of dexamethasone on the 2nd day of culture and continued for four days. They were removed from the wells after incubation with collagenase solution at $37^{\circ} \mathrm{C}$ for $1 \mathrm{~h}$. Aliquots of the dispersed cells were counted electronically (Coulter Counter, Coulter Electronics Inc., Hialeah, Fla.) to determine cell numbers, or DNA was determined by the method of Burton (10).

To assay alkaline phosphatase activity, cells were treated with dexamethasone for the final $2 \mathrm{~d}$ in culture and assayed on the 7th day. Monolayers were digested with collagenase as in growth experiments, and the dispersed cells were washed thoroughly with phosphate-buffered saline and sonicated in $0.5 \mathrm{ml}$ of cold buffer containing $10 \mathrm{mM}$ Tris and $0.1 \%$ sodium deoxycholate ( $\mathrm{pH}$ 7.4). Aliquots of the sonicate were assayed for phosphatase activity at $\mathrm{pH} 10.1$ by the method of Lowry (11) with $4 \mathrm{mM}$ of $p$-nitrophenyl phosphate (Sigma Chemical Co., St. Louis, Mo.) as substrate.

Adenylate cyclase assay. Cells pretreated with or without dexamethasone in liter-size bottles were dispersed by collagenase, and the washed cells were disrupted in hypotonic buffer B ( $10 \mathrm{mM}$ Tris, $1 \mathrm{mM}$ EDTA, $1 \mathrm{mM}$ dithiothreitol) with a Dounce homogenizer. Then, a volume of $2 \mathrm{M}$ sucrose was added to bring the sucrose concentration to $0.25 \mathrm{M}$. The homogenate was centrifuged at $200 \mathrm{~g}$ for $10 \mathrm{~min}$, and the supernate was removed and recentrifuged at $30,000 \mathrm{~g}$ for $10 \mathrm{~min}$. The upper white-colored fraction of the pellet was gently removed by aspiration with a Pasteur pipet. This membrane fraction was resuspended by gentle homogenization in the same buffer containing $0.25 \mathrm{M}$ of sucrose. Aliquots of the membrane suspension containing $25-50 \mu \mathrm{g}$ of protein were used for the assay. Adenylate cyclase activity was measured by a modification of the method described by Marcus and Orner (12). An aliquot of the membrane fraction was added to the reaction mixture to initiate the reaction. The final reaction mixture contained in a $100-\mu \mathrm{l}$ vol: $50 \mathrm{mM}$ of Tris buffer ( $\mathrm{pH} 7.4$ ), $0.5 \mathrm{mM}$ of $\mathrm{MgCl}_{2}, 30 \mathrm{mM} \mathrm{KCl}, 0.015 \%$ BSA, $0.5 \mathrm{mM}$ isobutylmethyl xanthine, $1 \mathrm{mM} \mathrm{ATP,} 4 \mathrm{mM}$ creatine phosphate, $20 \mu \mathrm{g}$ creatine phosphokinase, and PTH, guanylyl imidodiphosphate $\left(\mathrm{G}_{\mathrm{p} p}[\mathrm{NH}]_{\mathrm{p}}\right)$, or $\mathrm{NaF}$ as indicated. Incubations were performed at $30^{\circ} \mathrm{C}$ for $15 \mathrm{~min}$ and terminated by the addition of $100 \mu \mathrm{l}$ of $25 \mathrm{mM}$ EDTA in $0.05 \mathrm{M}$ sodium acetate and acetic acid buffer ( $\mathrm{pH}$ 6.2) followed by boiling for $3 \mathrm{~min}$. The boiled mixture was centrifuged for $10 \mathrm{~min}$ at $2,000 \mathrm{~g}$, and aliquots of supernate were assayed for cAMP by radioimmunoassay. The antigen, ${ }^{125}$ I-succinyl cAMPtyrosine methyl ester was obtained from Collaborative Research Inc. (Waltham, Mass.). The antibody was obtained from 
Research Products International Corp. (Elk Grove Village, IIl.), and the method was adapted from the standard $\left(\mathrm{NH}_{4}\right)_{2} \mathrm{SO}_{4}$-precipitation method as described by Collaborative Research Inc. except that the antigen-antibody complex was precipitated with BSA and ethanol as described by Frandson and Krishna (13).

Phosphodiesterase assay. Cells cultured in 6-oz bottles, pretreated for $2 \mathrm{~d}$ with vehicle or varying amounts of dexamthasone, were used in these experiments. Cells were homogenized in cold, $0.25-\mathrm{M}$ sucrose after removal from the bottles and washing with phosphate-buffered saline. cAMP phosphodiesterase activity of the homogenate was measured by the method of Marcus (14) with minor modifications as described earlier (7). DNA was extracted from the 2,000 $\mathrm{g}$ pellet with $10 \%$ perchoric acid and assayed by the method of Burton (10).

\section{RESULTS}

Differentially enriched bone-cell populations. The possibility of obtaining subpopulations of bone cells differentially enriched for $\mathrm{OB}$ and $\mathrm{OC}$ cells was pursued with a combination of the methods described by Wong and Cohn (5) and Peck et al. (6). By both methods, the superficial or early-released cells responded to CT with a cAMP rise that was not seen in the deeper or later-released cells. On the other hand, although PTH stimulated deep and superficial cell populations, a gradient existed with maximal cAMP generation seen in the deeper cells and less stimulation in the superficial cells (Fig. 1). In our hands, use of the scraping technique to obtain superficial cells proved variable. In all experiments shown, the cell population obtained with a 30 -min digestion period, is designated OC. The population of cells harvested between 30 and $120 \mathrm{~min}$ of enzyme exposure is designated OB. Although the data are similar to those of Wong and Cohn (5), we prefer these designations because our methods and species differed from those workers.

Glucocorticoid receptors in bone cells. We have previously demonstrated the presence of glucocorticoid receptors in mixed, freshly harvested (1) and cultured bone cells (2). Although we felt those cells were predominantly osteoblasts because they were obtained after periosteal scraping, at the time those studies were performed we were unable to examine differentially separated populations of cells for the presence of receptors. With the present method, it was now possible to perform binding studies on separated cells. Fig. 2 shows a Scatchard analysis of $\left[{ }^{3} \mathrm{H}\right]$ dexamethasonebinding experiments employing cytosol obtained from $\mathrm{OB}$ and $\mathrm{OC}$ cells. The number of binding sites is the same in $\mathrm{OB}$ and $\mathrm{OC}$ cells $(\cong 400 \mathrm{fmol} / \mathrm{mg}$ cytosol protein). The apparent $K_{d}$ is also equivalent in both cell types $(\cong 5 \mathrm{nM})$. From these results and additional studies such as competition profiles against a variety of steroids (data not shown), we conclude that both cell types possess glucocorticoid receptors, and the

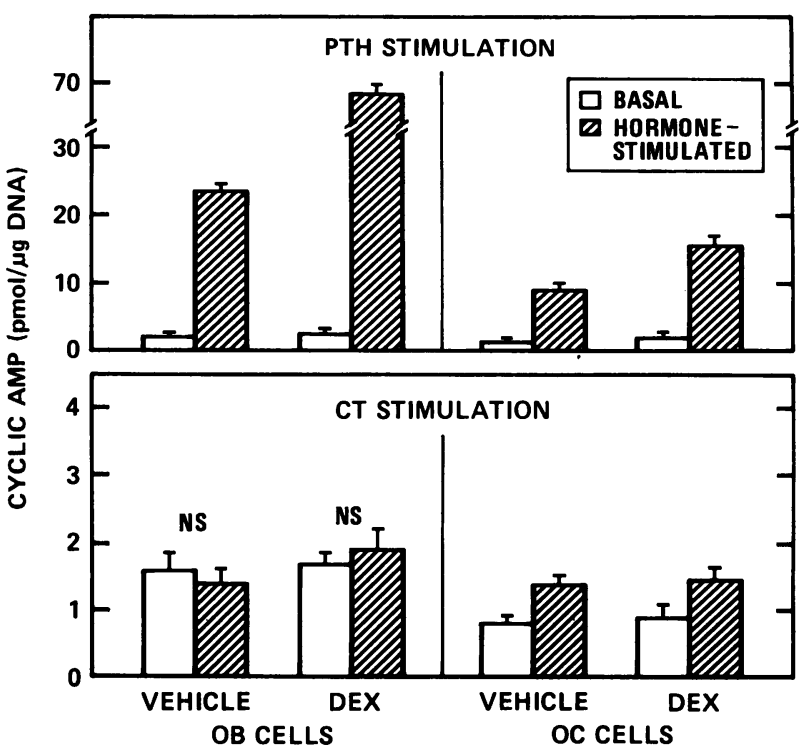

Figure 1 The effect of dexamethasone (DEX) on PTHand CT-stimulated CAMP production in $\mathrm{OB}$ and $\mathrm{OC}$ cells. OC cells were obtained during the first $30 \mathrm{~min}$ of collagenase digestion, and $O B$ cells were released between 30 and 120 min. Cells were cultured for $5 \mathrm{~d}$, and then one-half of the cells in each population were treated with vehicle $(0.05 \%$ ethanol) or $13 \mathrm{nM}$ dexamethasone for an additional $2 \mathrm{~d}$. After a total of $7 \mathrm{~d}$ in culture, when cells reached confluency, PTH- $(0.06 \mu \mathrm{g} / \mathrm{ml})$ and CT- $(0.12 \mu \mathrm{g} / \mathrm{ml})$ stimulated cAMP was measured after 2-min stimulation with hormones. Values are means $\pm \mathrm{SE}$ of four samples each. For PTH stimulation, dexamethasone-treated OB cells were significantly higher than vehicle-treated cells at $P<0.001$; $P<0.05$ for the same comparison in OC cells. No significant difference was shown by CT stimulation in either cells between vehicle and dexamethasone treatments.

glucocorticoid binding properties in these two subpopulations are similar, if not identical.

Dexamethasone effects on cell growth. We previously found that glucocorticoid addition to bone cell cultures had an antiproliferative action when the steroids were added in the early phases of the culture period (2). These findings are expanded in the present study and, as shown in Table I, dexamethasone caused a dose-dependent inhibition of the growth of both $\mathrm{OB}$ and $\mathrm{OC}$ cells. However, in confirmation of the observations of Runikis et al. (15) with fibroblasts, glucocorticoid addition to cultured bone cells at or near confluency did not reduce, and could perhaps increase, the DNA content of either OB or OC cells (Table I). (Cell counts were used in the early treatment experiments because of the low DNA values under such culture conditions). Dexamethasone treatment of cells for the last $2 \mathrm{~d}$ in culture thus provided a protocol which allowed examination of other glucocorticoidmediated functions without alterations in the cell population. This protocol was used in all subsequent experiments. 


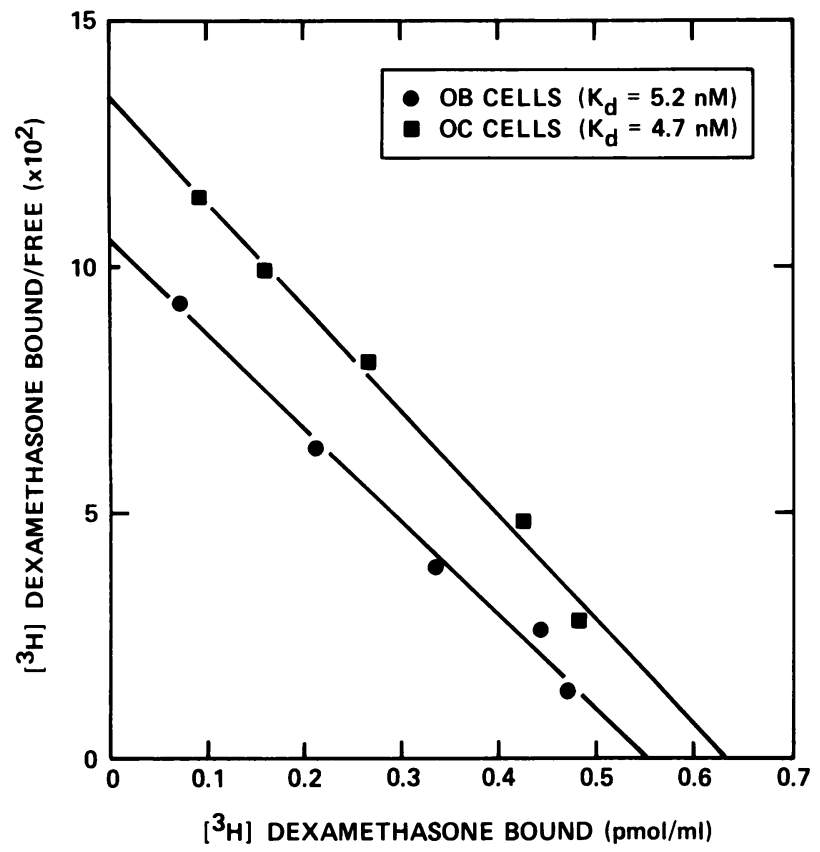

FIGURE 2 Scatchard analysis of $\left[{ }^{3} \mathrm{H}\right]$ dexamethasone-binding in cytosol from $O B$ and $O C$ cells. Cells from confluent cultures were washed and disrupted in hypotonic buffer. Cytosols $(50,000 \mathrm{~g}$ supernates) were incubated with varying concentrations of $\left[{ }^{3} \mathrm{H}\right]$ dexamethasone at $0^{\circ} \mathrm{C}$ for $4 \mathrm{~h}$. Bound and free steroid were separated by a charcoal-dextran adsorption method. To obtain specific bound counts, nonspecific binding performed in the presence of 250 -fold excess of cold dexamethasone was subtracted from the total binding. The protein concentration is $1.4 \mathrm{mg} / \mathrm{ml}$ for $\mathrm{OB}$ cells and $1.6 \mathrm{mg} / \mathrm{ml}$ for OC cells.

Dexamethasone regulation of alkaline phosphatase activity. Dexamethasone treatment of cultured cells early in the culture period, when cell numbers were inhibited by steroid exposure, failed to alter alkaline phosphatase activity (2). However, dexamethasone addition to cultures when DNA values were unaltered did lead to inhibition of alkaline phosphatase activity (Table II). The basal level of alkaline phosphatase activity is very high in OB cells; OC cells possessed about one-sixth the activity. Both populations showed a similar dose-dependent inhibition of enzyme activity in response to dexamethasone addition late in the culture period.

Dexamethasone modulation of PTH and CT stimulation of cAMP generation. We previously showed that dexamethasone potentiated the ability of PTH to stimulate cAMP in mixed bone cells (7). In the present study, we examined the effects of dexamethasone separately on OB and OC cells and for both PTH and CT stimulation. Fig. 1 illustrates the results of treating bone cells with $13 \mathrm{nM}$ dexamethasone for the last $2 \mathrm{~d}$ in culture. This concentration of dexamethasone is slightly below the dose which achieves saturation of the receptor sites. The cells were then exposed to either PTH or CT for $2 \mathrm{~min}$, and cAMP was measured. Pilot experiments determined that this was the time of peak cAMP generation (7). Dexamethasone treatment did not measurably alter basal levels of cAMP in either OB or OC cells. The ability of PTH to stimulate cAMP was greatly potentiated by glucocorticoid treatment in OB cells. A similar effect was present but much less marked in OC cells. CT did not stimulate cAMP production in $\mathrm{OB}$ cells in the presence or absence of dexamethasone (Fig. 1). Although CT did stimulate cAMP in OC cells, the CT effect was not potentiated by dexamethasone treatment.

Glucocorticoid potentiation of PTH-stimulated cAMP generation could be the result of dexamethasone-

TABLE I

Effect of Dexamethasone on Cell Growth and DNA Content at Different Growth Phases in Culture

\begin{tabular}{|c|c|c|c|c|}
\hline \multirow[b]{2}{*}{ Dexamethasone } & \multicolumn{2}{|c|}{ Early treatment } & \multicolumn{2}{|c|}{ Late treatment } \\
\hline & OB cells & OC cells & OB cells & OC cells \\
\hline$n M$ & \multicolumn{2}{|c|}{$10^{5}$ cells $/$ culture } & \multicolumn{2}{|c|}{$\mu g$ DNA/culture } \\
\hline 0 & $4.3 \pm 0.2(100 \%)$ & $4.0 \pm 0.2(100 \%)$ & $23.8 \pm 0.4(100 \%)$ & $22.5 \pm 0.8(100 \%)$ \\
\hline 0.13 & $4.1 \pm 0.2(95 \%)$ & $3.9 \pm 0.1(98 \%)$ & $22.8 \pm 1.3(96 \%)$ & $22.5 \pm 1.6(100 \%)$ \\
\hline 1.3 & $3.7 \pm 0.1(87 \%)$ & $3.7 \pm 0.1(93 \%)$ & $23.3 \pm 1.2(98 \%)$ & $21.4 \pm 1.8(95 \%)$ \\
\hline 13.0 & $3.2 \pm 0.1(76 \%)$ & $3.1 \pm 0.2(77 \%)$ & $25.1 \pm 1.7(105 \%)$ & $27.6 \pm 1.2(123 \%)$ \\
\hline 130.0 & $3.0(n=2 ; 69 \%)$ & $3.0 \pm 0.1(76 \%)$ & - & - \\
\hline
\end{tabular}

In early treatments, cells in $1.6-\mathrm{cm}^{2}$ plastic wells were treated the 2 nd day in culture with vehicle $(0.05 \%$ ethanol) or varying concentrations of dexamethasone for $4 \mathrm{~d}$. After release from culture wells with collagenase, cell numbers were determined with a Coulter Counter. Values are mean $\pm \mathrm{SE}$ of four cultures each. In late treatments, cells in 6-oz glass bottles were treated on the 5th day for the last $2 \mathrm{~d}$ in culture. DNA content was measured in perchloric acid extracts of cell pellets. Values are mean $\pm \mathrm{SE}$ of six to eight cultures. Values shown in parentheses are percentages of vehicle-treated cells. 
TABLE II

Inhibition of Alkaline Phosphatase Activity by Dexamethasone in $O B$ and $O C$ Cells

\begin{tabular}{ccc}
\hline \multirow{2}{*}{ Dexamethasone } & \multicolumn{2}{c}{ Alkaline phosphatase activity } \\
\cline { 2 - 3 } OB cells & OC cells \\
\hline$n M$ & \multicolumn{2}{c}{ nmol/mg protein/min } \\
0 & $367 \pm 23(100 \%)$ & $79 \pm 4(100 \%)$ \\
0.26 & $313 \pm 10(85 \%)$ & $65 \pm 1(82 \%)$ \\
2.6 & $273 \pm 5(74 \%)$ & $59 \pm 1(75 \%)$ \\
26 & $253 \pm 4(69 \%)$ & $53 \pm 1(67 \%)$ \\
260 & $229 \pm 8(62 \%)$ & $47 \pm 1(59 \%)$ \\
\hline
\end{tabular}

Cells were treated with vehicle $(0.05 \%$ ethanol) or varying concentrations of dexamethasone near confluency for the last $2 \mathrm{~d}$ of a total of $7 \mathrm{~d}$ in culture. Alkaline phosphatase activity was measured as described in Methods. Values are mean $\pm \mathrm{SE}$ of four cultures each. DNA was unchanged by dexamethasone treatment. Values in parentheses are percentages of vehicle-treated cells.

induced changes in the rate of either cAMP synthesis or degradation. We, therefore, next attempted to ascertain whether dexamethasone altered adenylate cyclase activity and(or) cAMP phosphodiesterase activity.

Dexamethasone effects on adenylate cyclase activity. Adenylate cyclase activity in the membrane fraction prepared from vehicle or dexamethasone-pretreated cells was measured in three states: basal, after PTH stimulation, and after $\mathrm{NaF}$ activation. As shown in Fig. 3, pretreatment with dexamethasone did not alter

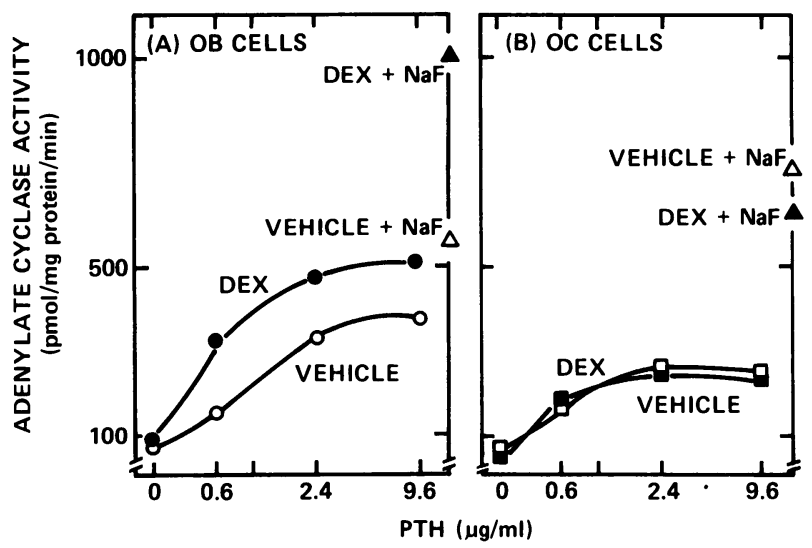

FIGURE 3 The effect of dexamethasone (DEX) on adenylate cyclase activity in $O B$ and $O C$ cells. Crude membrane fractions prepared from cells treated with vehicle or 13 $\mathrm{nM}$ dexamethasone for the last $2 \mathrm{~d}$ in culture were used as a source of enzyme. Adenylate cyclase activity was measured with $1 \mathrm{mM}$ of ATP as substrate and in the presence of an ATP-regenerating system. The amount of cAMP formed was measured by radioimmunoassay. The values are means of three to five samples of duplicate assays from two experiments. basal cyclase activity in either population. However, PTH-stimulated cyclase activity was increased in dexamethasone-treated OB cells at every dose of PTH employed. Moreover, $\mathrm{NaF}$-activated adenylate cyclase of $\mathrm{OB}$ cells was greatly increased by dexamethasone. On the other hand, dexamethasone caused only insignificant changes in the adenylate cyclase in OC cells in all three states.

Guanosine triphosphate and its analogues are known to cause an enhancement of adenylate cyclase activity $(16,17)$. To examine whether the guanosine triphosphate nucleotides are involved in dexamethasone potentiation of the enzyme activity, adenylate cyclase assays were performed with and without $\mathrm{G}_{\mathrm{pp}}(\mathrm{NH})_{\mathrm{p}}$, a stable analogue of guanosine triphosphate. As shown in Table III, $\mathrm{G}_{\mathrm{pp}}(\mathrm{NH})_{\mathrm{p}}$ addition caused an increase in basal and PTH-stimulated enzyme activity when compared with the groups without added $\mathrm{G}_{\mathrm{pp}}(\mathrm{NH})_{\mathrm{p}}$. An additional increment in enzyme activity was observed in cells treated with $G_{p p}(N H)_{p}$ plus dexamethasone. These results imply that dexamethasone potentiates enzyme activity by a mechanism other than $\mathrm{G}_{\mathrm{pp}}(\mathrm{NH})_{\mathrm{p}}$.

Dexamethasone effects on phosphodiesterase activity. In addition to stimulating adenylate cyclase activity, dexamethasone might modulate the cAMP-generating system by inhibiting cAMP phosphodiesterase. We have previously presented preliminary evidence that this was the case in mixed bone cells (7). Table IV depicts the ability of increasing concentrations of dexamethasone to inhibit phosphodiesterase in both $\mathrm{OB}$ and $\mathrm{OC}$ cells. As opposed to alterations in adenylate cyclase, which was demonstrable in $\mathrm{OB}$ cells only, the dexamethasone effects on phosphodiesterase are roughly equivalent in both populations of cells.

Effect of dexamethasone on the kinetics of PTHstimulated cAMP generation. Thus far, the data indicate that dexamethasone inhibits phosphodiesterase activity in both $\mathrm{OB}$ and $\mathrm{OC}$ cells but enhances stimulatable adenylate cyclase activity in $\mathrm{OB}$ cells only. We next explored the dose-response kinetics of PTH stimulation of CAMP in vehicle- and dexamethasonetreated cells. As shown in Fig. 4, dexamethasone treatment increased the sensitivity of OB cells to PTH and also increased the maximal amount of cAMP generated. The results in OC cells were similar. The PTH stimulation in this study was performed on cells scraped from culture bottles and resuspended in small tubes. After scraping, we routinely found a significant decrease in both base-line and PTH-stimulated CAMP production from $\cong 0.1$ to 0.2 of the value obtained with the undisturbed monolayer. However, the relative rise in CAMP after PTH stimulation, and the extent of the dexamethasone potentiation, remained constant (Figs. 1 and 4). 
TABLE III

Effect of $G_{p p}(\mathrm{NH})_{p}$ on Dexamethasone Potentiation of Adenylate Cyclase Activity in $O B$ Cells

\begin{tabular}{|c|c|c|c|c|}
\hline \multirow[b]{3}{*}{ PTH } & \multicolumn{4}{|c|}{ Adenylate cyclase activity } \\
\hline & \multicolumn{2}{|c|}{ Vehicle } & \multicolumn{2}{|c|}{ Dexamethasone } \\
\hline & $-\mathrm{G}_{\mathrm{pp}}(\mathrm{NH})_{\mathrm{p}}$ & $+\mathrm{G}_{\mathrm{pp}}(\mathrm{NH})_{\mathrm{p}}$ & $-\mathrm{G}_{\mathrm{pp}}(\mathrm{NH})_{\mathrm{p}}$ & $+\mathrm{G}_{\mathrm{pp}}(\mathrm{NH})_{\mathrm{p}}$ \\
\hline$\mu g / m l$ & \multicolumn{4}{|c|}{ pmol cAMP/mg protein/min } \\
\hline 0 & $70.1 \pm 6.6$ & $112.2 \pm 3.2 *$ & $78.5 \pm 9.4$ & $190.1 \pm 11.1^{*}$ \\
\hline 0.6 & $150.8 \pm 3.1$ & $214.1 \pm 10.0 \ddagger$ & $225.8 \pm 16.9$ & $313.7 \pm 17.0 *$ \\
\hline 9.6 & $216.7 \pm 6.8$ & $307.7(14.3)$ & $299.3 \pm 8.1$ & $401.4(6.2)$ \\
\hline
\end{tabular}

OB cells were treated with vehicle $(0.05 \%$ ethanol) or dexamethasone $(13 \mathrm{nM})$ for the last $2 \mathrm{~d}$ in culture. Adenylate cyclase activity was assayed in crude membrane fractions with varying concentrations of PTH with or without 10 $\mathrm{mM}$ of $\mathrm{G}_{\mathrm{pp}}(\mathrm{NH})_{\mathrm{p}}$. Values represent mean $\pm \mathrm{SE}$ of four assays except for the groups stimulated with $9.6 \mu \mathrm{g} / \mathrm{ml}$ of PTH in the presence of $\mathrm{G}_{\mathrm{pp}}(\mathrm{NH})_{\mathrm{p}}$ which represent mean and range (in parentheses) of two assays.

* Significantly different from $-\mathrm{G}_{\mathrm{pp}}(\mathrm{NH})_{\mathrm{p}}$ treatment at $P<0.05$.

$\$$ Significantly different from $-\mathrm{G}_{\mathrm{pp}}(\mathrm{NH})_{\mathrm{p}}$ treatment at $P<0.001$.

\section{DISCUSSION}

This study confirms the findings of other workers $(5,6)$ that bone cells obtained from neonatal rodent calvaria can be resolved into separate populations enriched for $\mathrm{OB}$ and OC cells (Table I, Fig. 1). The enrichment method is based on the anatomical localization of the cells in calvaria: $O C$ at the surface and $O B$ in a deeper location. The $O B$ population appears to be predominantly made up of osteoblasts. The cells contain high levels of alkaline phosphatase and respond primarily to PTH stimulation (Fig. 1, Table II); in contrast, the OC population responds both to PTH and CT (Fig. 1). The OC population probably represents a heterogenous collection of cells, some of which are osteoclasts or at least CT-responsive, and some of which may be osteoblasts or osteocytes. The rise

\section{TABLE IV}

Inhibition of cAMP Phosphodiesterase Activity by Dexamethasone in $O B$ and $O C$ Cells

\begin{tabular}{ccc}
\hline \multirow{2}{*}{ Dexamethasone } & \multicolumn{2}{c}{ cAMP phosphodiesterase activity } \\
\cline { 2 - 3 } & OB cells & OC cells \\
\hline$n . M$ & pmol cAMP hydrolyzed/mp DNA \\
0 & $122 \pm 2(100 \%)$ & $88 \pm 2(100 \%)$ \\
0.13 & $98 \pm 2(80 \%)$ & $75 \pm 3(85 \%)$ \\
1.3 & $75 \pm 5(61 \%)$ & $52 \pm 5(59 \%)$ \\
13 & $52 \pm 5(43 \%)$ & $39 \pm 3(44 \%)$ \\
\hline
\end{tabular}

Cells were treated as described in Table II. Values are means $\pm \mathrm{SE}$ of three cultures each. DNA was unchanged by dexamethasone treatment. Values in parentheses are percentages of vehicle-treated cells. in cAMP stimulated by CT was low in our fetal rat cells when compared with the results of other investigators employing cells from newborn mice (5). Because this response is determined by the number of CT-responsive cells in the population, it may vary with the age and species of the animals employed, the enzymes and techniques used to isolate the cells, and the culture conditions. Other workers

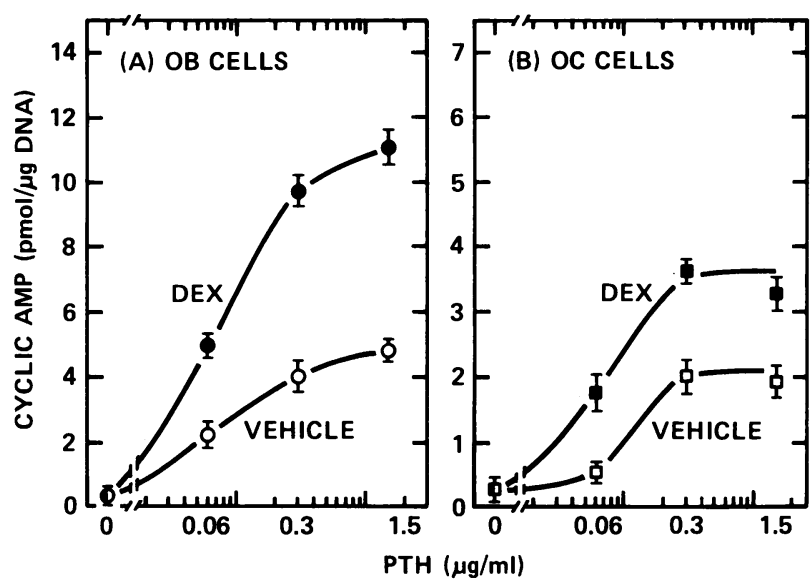

FIgure 4 Dexamethasone (DEX) potentiation of cAMP generation stimulated by varying doses of PTH. Cells were treated with vehicle or $13 \mathrm{nM}$ dexamethasone for the last $2 \mathrm{~d}$ in culture. Before PTH stimulation, cells scraped from glass bottles were suspended in $1 \mathrm{ml}$ of BSA medium and stimulated with vehicle $(5 \mathrm{mg} / \mathrm{ml} \mathrm{BSA}$ in $5 \mathrm{mM}$ acetic acid) or varying concentrations of PTH for 2 min. Cells were immediately centrifuged, the medium removed, and cold, $100 \%$ ethanol added to terminate the reaction. The amount of cAMP in the cell extracts was measured by the protein-binding method. Each point represents the mean of four samples $\pm \mathrm{SE}$. 
failed to observe any cAMP rise after CT stimulation of fetal rat bone cell populations isolated and cultured under conditions similar to ours (18). The data suggest that newborn mice may be a better source of OC cells than fetal rat.

A possibility requiring consideration is that the rise in cAMP in OC cells after PTH stimulation is totally a result of contamination by $O B$ cells. However, the magnitude of the CAMP response and the amount of contamination estimated by alkaline phosphatase activity does not support this hypothesis. The cAMP generated at any given dose of PTH in OC cells is $\cong 50 \%$ that of $\mathrm{OB}$ cells (Figs. 1 and 4 ). However, the maximal overlap of $\mathrm{OB}$ cells into the $\mathrm{OC}$ population is approximately one-sixth, assuming that OC cells do not possess any alkaline phosphatase activity at all (Table II). We conclude that some non-OB cells in the OC population respond to PTH stimulation. However, a recent report by Goldring et al. (19) indicates that the CAMP response to PTH may be more widespread than previously considered.

Both cell populations were found to possess glucocorticoid receptors (Fig. 2), which suggests that both cell types are glucocorticoid targets. In spite of other biochemical differences between the OB and OC cells, both populations possessed the same concentration of glucocorticoid receptors (Fig. 2), and the properties of the receptor appeared to be identical in the two cell types resembling glucocorticoid receptors described in other target tissues (20). The concentration of receptors is high: $\cong 400 \mathrm{fmol} / \mathrm{mg}$ cytosol protein or 14,400 sites per cell, assuming one steroid molecule per site. These values compare favorably with other conventional glucocorticoid target tissues (20), which suggests that all or most cells contain receptors. This idea is supported by cell growth experiments which showed that even the cells resistant to the antiproliferative action of dexamethasone possessed equivalent concentrations of receptors.

Functional studies indicated that glucocorticoid treatment was inhibitory to both populations. When administered early in the culture period, dexamethasone elicited dose-dependent inhibition of $\mathrm{OB}$ and $\mathrm{OC}$ cell growth (Table I). Alkaline phosphatase activity was inhibited in both populations, even at times in the culture period when dexamethasone failed to exhibit its antiproliferative action (Table II). The two populations appear equally responsive to glucocorticoid as evidenced by an equivalent degree of inhibition.

We have previously shown that glucocorticoids potentiate PTH stimulation of CAMP production in mixed bone cell cultures (7). In the present study, we examined the ability of glucocorticoid to alter the cAMP response of separated $\mathrm{OB}$ and $\mathrm{OC}$ cells to $\mathrm{PTH}$ and CT. The findings were that dexamethasone did significantly potentiate the cAMP response to PTH in OC cells as well as OB cells (Figs. 1 and 4). The mechanism by which glucocorticoids potentiate the cAMP response was next examined. We previously reported an inhibition of phosphodiesterase by dexamethasone in a mixed population of bone cells (7). The present data show an equivalent glucocorticoid inhibition of phosphodiesterase activity in both populations. Because of the differences in cAMP potentiation in $\mathrm{OB}$ and $\mathrm{OC}$ cells (Fig. 1), simple alterations in phosphodiesterase can not completely explain the cAMP data.

The second possible mechanism by which glucocorticoids might potentiate PTH-stimulated CAMP is by activation of the adenylate cyclase system. Stimulation of adenylate cyclase activity was found in OB cells but not OC cells (Fig. 3). NaF-stimulatable cyclase activity was doubled in $\mathrm{OB}$ cells as was the enzyme response to all concentrations of PTH. These data suggest that glucocorticoids increased the endogenous enzyme activity. Although the basal activity of enzyme was not measurably increased by dexamethasone, changes in enzyme content may not be detectable at the low activity level of unstimulated enzyme.

The molecular mechanisms regulating adenylate cyclase activity are very complex (15, 16). An additional possibility was that glucocorticoid treatment enhanced the production or activation of some regulatory component(s) or facilitated the interaction of PTH with its active site on the enzyme. The possibility of the involvement of guanosine triphosphate in the glucocorticoid potentiation of adenylate cyclase was pursued. It was found that $G_{p p}(\mathrm{NH})_{p}$ increased basal activity while dexamethasone did not (Table III). Moreover, dexamethasone caused a further potentiation of enzyme activity than that caused by the addition of $10 \mu \mathrm{M} \mathrm{G} \mathrm{G}_{\mathrm{pp}}(\mathrm{NH})_{\mathrm{p}}$ (Table III) or $100 \mu \mathrm{M}$ $G_{p p}(N H)$ (data not shown). Therefore, the glucocorticoid stimulation of enzyme activity is apparently not via a $G_{p p}(N H)_{p}$ mechanism.

The glucocorticoid action to potentiate $\mathrm{PTH}$ stimulated cAMP exhibited both an increase in sensitivity to PTH as well as the attainment of higher maximal levels of cAMP (Fig. 4). The effect was qualitatively similar in both cell types although quantitatively different. Because inhibition of phosphodiesterase and stimulation of adenylate cyclase were found in $O B$ cells, while only inhibition of phosphodiesterase was detected in OC cells, it is difficult to ascribe an action to the change in each enzyme. It is possible that we failed to detect a stimulation of adenylate cyclase in a subpopulation of OC cells.

An additional mechanism which has to be considered is that glucocorticoid treatment induced the synthesis of additional PTH receptors. Recent evidence suggests 
that glucocorticoids may regulate the concentration of receptors for other hormones $(21,22)$. Although we did not test this thesis directly, we found, in fact, that another stimulator of cAMP, prostaglandin $E_{1}$, also exhibited a similar glucocorticoid-induced potentiation of cAMP generation in both cell populations. ${ }^{2}$ Thus, if glucocorticoids act at the membrane receptor level, we must postulate that multiple receptors are induced.

The present studies indicate that glucocorticoids exhibit two different types of action directly at the bone cell level. Both actions are seen in both OBand OC-cell types. The first action is a general inhibitory effect, which is also seen in many other tissues $(23,24)$. The expectation is that this action would result in reduced bone formation as well as a reduced rate of bone resorption because of an inhibition of OB- and OC-cell proliferation and function. The second action is a potentiation of PTH-stimulated CAMP production. PTH inhibits OB cell activity and decreases collagen formation $(25,26)$. cAMP is considered the intracellular mediator of these effects (26). Therefore, by potentiating PTH action, glucocorticoids may inhibit OB cells by a second pathway.

The direct inhibition of OC cells by glucocorticoids may possibly provide an explanation for the findings that glucocorticoids inhibit PTH-mediated bone resorption in organ culture after brief exposure to low doses of PTH (27-29). However, cAMP is considered the likely second messenger for PTH-mediated bone resorption, although this remains controversial (27). Thus, the steroid action to enhance PTH-stimulated cAMP may potentially increase bone resorption. Our findings of two glucocorticoid actions provides for a possible increase or decrease in OC cell activity. Which action prevails, either inhibition of OC cells directly or potentiation of PTH action, is probably determined by the relative concentrations of hormones as well as other still unknown factors.

In summary, this paper has described direct actions of glucocorticoids on rat bone cells in culture. The findings suggest that $\mathrm{OB}$ cells are inhibited both directly and by a potentiation of PTH action, whereas OC cells are directly inhibited but potentiation of PTH-stimulated CAMP may lead, at least theoretically, to enhanced resorption. These consequences of glucocorticoid actions are consistent with current interpretations of bone morphology in patients exposed to excess corticosteroids (30).

\section{ACKNOWLEDGMENTS}

We thank Margaret A. Hirst for excellent technical assistance.

This study was supported by National Institutes of Health grant AM19675.

${ }^{2}$ Chen, T. L., and D. Feldman. Manuscript in preparation.

\section{REFERENCES}

1. Feldman, D., R. Dziak, R. Koehler, and P. Stern. 1975. Cytoplasmic glucocorticoid binding proteins in bone cells. Endocrinology. 96: 29-36.

2. Chen, T. L., L. Aronow, and D. Feldman. 1977. Glucocorticoid receptors and inhibition of bone cell growth in primary culture. Endocrinology. 100: 619-628.

3. Peck, W. A., J. Brandt, and I. Miller. 1967. Hydrocortisoneinduced inhibition of protein synthesis and uridine incorporation in isolated bone cells. Proc. Natl. Acad. Sci. U. S. A. 57: 1599-1606.

4. Choe, J., P. Stern, and D. Feldman. 1978. Receptor mediated glucocorticoid inhibition of protein synthesis in isolated bone cells. J. Steroid Biochem. 9: 265-271.

5. Wong, G. L., and D. V. Cohn. 1975. Target cells in bone for parathyroid hormone and calcitonin are different: Enrichment for each cell type by sequential digestion of mouse calvaria and selective adhesion to polymeric surfaces. Proc. Natl. Acad. Sci. U. S. A. 72: 3167-3171.

6. Peck, W. A., J. K. Burke, J. Wilkins, S. B. Rodan, and G. A. Rodan. 1977. Evidence for preferential effects of parathyroid hormone, calcitonin, and adenosine in bone and periosteum. Endocrinology. 100: 1357-1364.

7. Chen, T. L., and D. Feldman. 1978. Glucocorticoid potentiation of the adenosine $3^{\prime}, 5^{\prime}$-monophosphate response to parathyroid hormone in cultured rat bone cells. Endocrinology. 102: 589-596.

8. Gilman, A. G. 1970. A protein binding assay for adenosine 3' $^{\prime} 5^{\prime}$-cyclic monophosphate. Proc. Natl. Acad. Sci. U. S. A. 67: 305-312.

9. Bradford, M. M. 1976. A rapid and sensitive method for the quantitation of microgram quantities of protein utilizing the principle of protein-dye binding. Anal. Biochem. 72: 248-254.

10. Burton, K. 1956. A study of the conditions and mechanisms of the diphenylamine reaction for the colorimetric estimation of deoxyribonucleic acid. Biochem. J. 62: $315-323$.

11. Lowry, O. H. 1955. Micromethods for the assay of enzyme. II. Specific procedures. Alkaline phosphatase. Methods Enzymol. 4: 371-372.

12. Marcus, R., and F. B. Orner. 1977. Cyclic AMP production in rat calvaria. In vitro interaction of prostaglandin with parathyroid hormone. Endocrinology. 101: 1570-1578.

13. Frandson, E. K., and G. Krishna. 1976. A simple ultrasensitive method for the assay of cyclic AMP and cyclic GMP in tissues. Life Sci. 18: 529-542.

14. Marcus, R. 1975. Cyclic nucleotide phosphodiesterase from bone: characterization of the enzyme and studies of inhibition by thyroid hormones. Endocrinology. 96: $400-408$.

15. Runikis, J. O., D. I. McLean, and W. D. Stewart. 1978. Growth-rate of cultured human fibroblasts increased by glucocorticoids. J. Invest. Dermatol. 70: 348-351.

16. Rodbell, M., L. Birnbaumer, S. L. Pohl, and H. M. J. Krans. 1971. The glucagon sensitive adenyl cyclase system in plasma membranes of rat liver. V. An obligatory role of guanyl nucleotides in glucagon action. J. Biol. Chem. 246: 1877-1882.

17. Perkins, J. P. 1973. Adenylate cyclase. In Advances in Cyclic Nucleotide Research. P. Greengard and G. A. Robison, editors. Raven Press, New York. 3: 1-164.

18. Rao, L. G., B. Ng, D. M. Brunette, and J. N. M. Heersche. 1977. Parathyroid hormone-response and prostaglandin $E_{1}$-response in a selected population of bone cells after repeated subculture and storage at $-80^{\circ} \mathrm{C}$. Endocrinology. 110: 1233-1241. 
19. Goldring, S. R., J. M. Dayer, R. G. G. Russell, H. J. Mankin, and S. M. Krane. 1978. Response to hormones of cells cultured from human giant cell tumors of bone. J. Clin. Endocrinol. Metab. 46: 425-433.

20. Feldman, D., J. Funder, and D. Loose. 1978. Is the glucocorticoid receptor identical in various target organs? J. Steroid Biochem. 9: 141-145.

21. Tashjian, A. H., Jr., R. Osborne, D. Maina, and A. Knaian. 1977. Hydrocortisone increases the number of receptors for thyrotropin releasing hormone on pituitary cells in culture. Biochem. Biophys. Res. Commun. 79: 333-340.

22. Marshall, S., H. H. Huang, G. S. Kledzik, G. A. Campbell, and J. Meites. Glucocorticoid regulation of prolactin receptors in kidneys and adrenals of male rats. Endocrinology. 102: 869-875.

23. Thompson, E. G., and M. E. Lippman. 1974. Mechanism of action of glucocorticoids. Metab. Clin. Exp. 23: 159-202.

24. Leung, K., and A. Munck. 1975. Peripheral actions of glucocorticoids. Annu. Rev. Physiol. 37: 245-272.

25. Luben, R. A., G. L. Wong, and D. V. Cohn. 1976. Biochemical characterization with parathyroid hormone and calcitonin of isolated bone cells. Provisional identification of osteoclasts and osteoblasts. Endocrinology. 99: $526-534$.

26. Dietrich, J. W., E. M. Canalis, D. M. Maina, and L. G. Raisz. 1976. Hormonal control of bone collagen synthesis in vitro. Effects of parathyroid hormone and calcitonin. Endocrinology. 98: 943-949.

27. Raisz, L. G. 1977. Bone metabolism and calcium regulation. In Metabolic Bone Disease. L. V. Avioli and S. M. Krane, editors. Academic Press, Inc., New York. 1: $1-48$.

28. Stern, P. H. 1969. Inhibition by steroids of parathyroid hormone induced $\mathrm{Ca}^{45}$ released from embryonic rat bone in vitro. J. Pharmacol. Exp. Ther. 168: 211-217.

29. Raisz, L. G., C. L. Trummel, J. A. Wener, and H. Simmons. 1972. Effect of glucocorticoids on bone resorption in tissue culture. Endocrinology. 90: 961-967.

30. Teitelbaum, S. L. 1977. Metabolic and nontumorous disorders of the bone. In Pathology. W. A. D. Anderson and J. M. Kissane, editors. The C. V. Mosby Company, St. Louis. 1905-1977. 